\title{
BOIS, CACHORROS, REIS BARBUDOS E MORTOS INSEPULTOS: O REALISMO MÁGICO NA LITERATURA BRASILEIRA PÓS GOLPE MILITAR DE 1964
}

\author{
João Luis Pereira Ourique ${ }^{1}$ \\ Douglas Eraldo dos Santos ${ }^{2}$
}

\begin{abstract}
Resumo: O presente artigo procura propor reflexões sobre a intensa presença do insólito e do realismo mágico na produção literária brasileira pós golpe militar de 1964. Este trabalho adota a relação entre literatura e sociedade para observar o respectivo contexto social e histórico e seu impacto na estética da produção literária pela ruptura com o modelo realista até então em vigor.
\end{abstract}

Palavras-chave: realismo mágico - literatura e sociedade - modelo realista

\begin{abstract}
The present article seeks to propose reflections about the intense presence of the magical realism in the Brazilian literary production after the 1964 military coup. This work adopts the relation between literature and society to observe the respective social and historical context and its impact on the aesthetics of the literary prodution by the rupture with the realistic model until then in force.
\end{abstract}

Keywords: magical realism - literature and society - realistic model

Principiamos nossas reflexões compartilhando o pensamento aceito por muitos pensadores de que os tempos amenos ${ }^{3}$ constituem nossas exceções, enquanto que os períodos de violência, opressão e autoritarismo fazem quase que a regra dos nossos distintos períodos sociais e históricos. A lembrança é necessária para não cairmos no engano de tratar como "exceção" o período histórico que compreende a abordagem presente neste artigo. Neste sentido, no caso da formação histórico-social brasileira, inúmeros são os momentos de deflagração da violência autoritária de modo que "em um mundo marcado pela experiência radical da destruição, o trauma se torna um elemento constitutivo da formação social" (GINZBURG, 2000, p.47). Partimos dessa premissa para compreendermos o período após o golpe militar de 1964 como mais um elemento constitutivo de nosso trauma coletivo e social, que embora não sendo uma "exceção", pelo tempo que perdurou e pela violência e censura existente durante sua vigência, tornou-se bastante significativo, e ainda hoje demanda reflexões e debates sobre estes anos sombrios. Nessa perspectiva, olhar para a literatura produzida durante este período se torna relevante não só para os estudos literários, mas também para todos aqueles que procuram entender e compreender aquele momento. Sobre ele, os anos 60, o crítico e sociólogo Antonio Candido diz:

O decênio de 1960 foi primeiro turbulento e depois terrível. A princípio, a radicalização generosa mas desorganizada do populismo, no governo João Goulart. Em seguida, graças ao pavor da burguesia e à atuação do imperialismo, o golpe militar

\footnotetext{
${ }^{1}$ Professor da Universidade Federal de Pelotas - UFPel. E-mail: jlourique@yahoo.com.br.

${ }^{2}$ Graduado em Letras Português na Universidade Federal de Pelotas - UFPel. E-mail: douglaseralldo@gmail.com.

${ }^{3}$ A utilização do termo "tempos amenos" pareceu-nos mais apropriada para uma lógica que nos leva a reconhecer, não somente o perdurar dos momentos de violência e autoritarismo em nossa formação social-histórica, mas também o reconhecimento de que, mesmo em situações como quando da reabertura democrática, ainda que em diferentes gradações, o autoritarismo presente em nossa estrutura social e na nossa cultura não desaparece por completo, sendo muitas vezes desnudado pela burocracia do Estado, pelas desigualdades sociais e econômicas, ou ainda, pela própria falência do Estado, quando, por exemplo, se mostra incapaz de gerir e criar políticas públicas eficientes no campo da educação, cultura e segurança, permitindo entre outras coisas que Estados paralelos, totalitários e autoritários, se estruturem em grandes periferias urbanas do país.
} 
de 1964, que se transformou em 1968 de brutalmente opressivo em ferozmente repressivo. (CANDIDO, 1989, p.207).

É geralmente aceito que o período da ditadura militar perdurou de 1964 até 1985 com o início da abertura política e a chegada do civil José Sarney à Presidência da República. Contudo, ainda sem a plenitude democrática, que veio a consolidar-se a partir da Constituinte de 1988 e posteriormente com as eleições gerais diretas de 1989. Sobre os distintos momentos da ditadura militar após 1964 vale observar o historiador Elio Gaspari que a divide em três momentos, a ditadura envergonhada, a ditadura escancarada e a ditadura encurralada. Há nisso convergência ao que Candido demonstra em sua reflexão, de um começo hesitante quando nos primeiros anos após o golpe militar, a partir de 1968 inicia-se o auge da repressão do regime, sendo daí até a metade da década de 70 (seu momento escancarado) seus anos mais violentos.

Neste ambiente tensionado e conflagrado e no qual a perseguição e a censura se intensificaram, no campo das artes e da literatura, Antonio Candido comenta que "o timbre dos anos 60 e sobretudo 70 foram as contribuições de linha experimental e renovadora, refletindo de maneira crispada, na técnica e na concepção da narrativa, esses anos de vanguarda estética e amargura política" (CANDIDO, 1989, p.208). Sobre a produção literária na década de 70, ele diz ainda:

pode-se falar em verdadeira legitimação da pluralidade. Não se trata mais de coexistência pacífica das diversas modalidades de romance e conto, mas do desdobramento destes gêneros, que na verdade deixam de ser gêneros, incorporando técnicas e linguagens nunca dantes imaginadas dentro de suas fronteiras. Resultam textos indefiníveis: romances que mais parecem reportagens; contos que não se distinguem de poemas ou crônicas, semeados de sinais e fotomontagens; autobiografias com tonalidade e técnica de romance; narrativas que são cenas de teatro; textos feitos com a justaposição de recortes, documentos, lembranças, reflexões de toda a sorte. (CANDIDO, 1989, p.208).

Nessa vanguarda estética por muito tempo concentraram-se as atenções da crítica e dos leitores aos chamados romances-reportagens, como é o caso do conhecido O Que É Isso Companheiro?, de Fernando Gabeira (1979). Antonio Candido, para além disso, aponta outra forte tendência deste momento literário, especificamente no campo da ficção:

Outra tendência é a ruptura, agora generalizada, do pacto realista (que dominou a ficção por mais de duzentos anos), graças à injeção de um insólito que de recessivo passou a predominante e, como vimos, teve nos contos do absurdo de Murilo Rubião o seu precursor. Com certeza foi a voga da ficção hispano-americana que levou para este rumo o gosto dos autores e do público. (CANDIDO, 1989 .p.210)

Nesta perspectiva, Antonio Candido apresenta dois elementos importantes: o primeiro é o fato de o crítico perceber a partir do insólito o avanço generalizado do fantástico no respectivo período, e seus laços com a ficção hispano-americana. O segundo evidencia o reconhecimento do precursionismo de Murilo Rubião em termos de Brasil, pois no final da década de 40 com a publicação de "Ex-mágico" (1947) ele começa a escrever seus contos dentro do gênero fantástico e suas gradações. Isso se dá em muitos casos concomitantemente ou mesmo precedendo a alguns autores hispano-americanos que fizeram do fantástic, e particularmente seu desdobramento, o Realismo Mágico ou Realismo Maravilhoso, uma das principais características da literatura na América Latina. É justamente aí que passa a residir o particular interesse deste artigo: observar o avanço do gênero fantástico, especialmente 
suas distintas gradações como o insólito, o realismo mágico e o real maravilhoso no período compreendido após o golpe militar de 1964.

Observar-se-á nestas reflexões, todavia, a grande complexidade categorial dos gêneros, complexidade da qual não está livre o fantástico, que comporta, por exemplo, as fícções científicas de Ignácio de Loyola Brandão, como é o caso de "Não Verás País Nenhum" (1981) a obras como "O Centauro No Jardim”, de Moacyr Scliar (1980). Em suma, dizemos aqui que levamos em consideração todas as polêmicas e distintas discussões que envolvem o termo "fantástico" e suas questões acerca de afiliações e subdivisões e mesmo origem decorrente de outros gêneros.

Por conseguinte, convém lembrar também que a presença do fantástico na literatura brasileira não é algo que se inicie apenas a partir do final da década de 40 e início da de 50 . Temos de considerar que há raízes dela em toda construção de nossa literatura. Gregório Dantas chega a falar de uma tradição do fantástico na literatura brasileira. E há de fato diversas discussões acerca da presença do fantástico na literatura nacional, como nas obras de Alvares de Azevedo, a quem muitos dizem tratarse provavelmente do primeiro autor brasileiro a adentrar o gênero, e mesmo parte da prolífica produção de Machado de Assis teria penetrado os terrenos do fantástico. As narrativas fantásticas encontrarão ainda grande espaço no modernismo brasileiro, vide o clássico "Macunaíma", de Mário de Andrade (1928) ou a ficção científica "O Presidente Negro", de Monteiro Lobato (1926). Contudo, no caso deste artigo concentraremo-nos na observação do trabalho José J. Veiga, especificamente seus romances $A$ "Hora dos Ruminantes" (1966) e "Sombras de Reis Barbudos" (1972), e Érico Veríssimo com "Incidente em Antares" (1971), refletindo sobre a relação entre estas obras e seus gêneros, seus o momentos sociais, históricos e estético-literários a que estavam inseridas.

Antes de avançarmos nossas reflexões, porém, é importante destacarmos algumas discussões acerca da problemática do fantástico na literatura. Uma das principais discussões sobre o fantástico é do linguista Tzvetan Todorov em "Introdução à Literatura Fantástica". É Todorov que limita o fantástico ao tempo da incerteza, como observamos:

O fantástico ocupa o tempo dessa incerteza; assim que escolhemos uma ou outra resposta, saímos do fantástico para entrar num gênero vizinho, o estranho ou o maravilhoso. $O$ fantástico é a hesitação experimentada por um ser que não conhece as leis naturais, diante de um acontecimento aparentemente sobrenatural. (TODOROV, 2006, p.147).

Em síntese, Todorov acaba restringindo o romance fantástico a determinados aspectos, colocando seus domínios entre o maravilhoso (quando pactuamos com a existência de seres fantásticos e sobrenaturais, como os contos de fadas ou as histórias de fantasmas) e o estranho (um campo amplo em que independente das estranhezas dos fatos, estes encontrariam explicações razoáveis e racionais). Assim, se no caso do fantástico as possibilidades ficam um tanto restritas, o campo do estranho, por exemplo, é um "mapa" de grande área e de diversas possibilidades. Seria, então, no estranho que se enquadraria o insólito?

[O] Insólito abarca aquilo que não é habitual, o que é desusado, estranho, novo, incrível, desacostumado, inusitado, pouco frequente, raro, surpreendente, decepcionante, frustrante, o que rompe com as expectativas da naturalidade e da ordem, a partir do senso comum, representante de um discurso oficial hegemônico. (GARCÍA, 2007, p. 1).

Existe uma percepção generalista de que é por este terreno que se movimenta José J. Veiga. Aliás, a questão da filiação das obras do autor também é tema de debate e discussão sobre sua pertencença. Uma observação relevante sobre esse aspecto é a de Antonio Arnoni Prado: 
Mas é bom lembrarmos que o próprio Veiga não gostava que o incluíssem entre os narradores fantásticos. Sempre que alguém o aproximava de um Murilo Rubião, de um García Márques ou até mesmo de um Julio Cortázar, ele fazia questão de corrigir: “A minha literatura é uma literatura realista: nem fantástica, nem mágica". Quer dizer: original e estranha sem sair da singular estranheza da nossa própria realidade. (PRADO, 2015, p.11).

Nesse debate, todavia, sem adentrarmos a este terreno tão rico de proposições e reflexões, observaremos aqui a dissertação de Gregório Foganholi Dantas em que ele se dedica ao "Insólito na Ficção de José J. Veiga".

Analisando as constantes temáticas e estilísticas da ficção de J. J. Veiga, chegamos à descrição do que optamos chamar de insólito, mais adequado ao autor goiano, em detrimento ao já desgastado fantástico. Pretendemos, afinal, demonstrar que a ficção de J. J. Veiga dialoga com o fantástico e com o realismo maravilhoso sem contudo de sujeitar estritamente a nenhum deles. (DANTAS, 2002, p.7).

O trabalho de Dantas é bastante completo e embrenha-se por toda a problemática de classificação da obra de Veiga, ao mesmo tempo que considera em suas argumentações os amplos estudos envolvendo a questão do fantástico no Brasil e na América Latina. Em termos de Brasil, o autor inclusive observa que:

Grande parte da crítica credita ao governo militar o que Lêdo Ivo chamou de "ploriferação incontrolável" da "literatura kafkiana", ou o que outros preferem chamar de "realismo mágico de 70". Este "gênero", se assim podemos chamá-lo, seria mais adequado para a crítica social. (DANTAS, 2002, pp.128-9).

Mas é a perspectiva da crítica social que nos interessa mais decisivamente, assim como esta percepção do avanço do gênero, ou dos diferentes gêneros de produção fantástica, após o golpe militar de 1964. Como visto, no período citado, mais do que uma vertente, mas sim um caminho escolhido por grande parte dos ficcionistas brasileiros, as narrativas, independente do caminhos fantásticos seguidos, se pelo insólito, pelo realismo mágico, a ficção científica ou o real maravilhoso, os autores em conjunto percorrem gêneros que possibilitem a tal ruptura com o pacto realista vigente. Do mesmo modo, vale reforçar que tais questões, diferentemente dos marcos geográficos, não possuem uma delimitação específica, uma espécie de placa sinalizadora de quando se inicia ou termina algo. O próprio Veiga começa sua produção literária anteriormente ao golpe de 1964, com seu livro de contos "Os Cavalinhos de Platiplanto" (1959), pelo qual Antonio Candido percebe e reconhece as características do conjunto da obra de Veiga e do próprio decênio. Ademais, antes deste período demarcado, temos ainda Murilo Rubião na década de 50, e mesmo a publicação de "O Coronel e o Lobisomem", de José Cândido de Carvalho em 1964, mesmo ano do golpe. Tais obras já traziam as características que marcariam especialmente as narrativas do final dos anos 60 e mais especificamente dos anos 70, quando a "ruptura" parece, portanto, surgir com força consolidada de movimento, em parte impactada pelos fatores externos à obra literária. O contexto externo, aliás, está claramente no horizonte de José J. Veiga como percebemos: 
É claro que Sombras, Os Pecados, Vasabarros foram contaminados pelo clima político contemporâneo deles, e a coincidência entre o clima interno e externo facilitou a leitura política. Mas meu projeto de escrevê-los não era ficar na mera denúncia de um regime de opressão: se fosse, os livros ficariam datados quando o regime exaurisse, como se exauriu (aliás, durou mais do que eu calculava). O meu projeto era mostrar situações mais profundas do que aquelas impostas por governinho de uns generaizinhos... (VEIGA apud RONCARI, 2015, p.17).

Um detalhe a atermo-nos nas respostas de Veiga sempre quando questionado da possibilidade da leitura alegórica de sua obra com o regime militar é que o autor sempre busca demonstrar o cuidado e a preocupação de não sucumbir ao simples planfetarismo, e, com isso datar sua produção. Tal consciência é provavelmente o que permite que suas obras permaneçam abertas a interpretações mais amplas, caso da publicação geralmente considerada a mais representativa de sua produção: "A Hora dos Ruminantes", de 1966. Poder-se-ia dizer que o romance, talvez seja o que melhor o afilie nos terrenos do insólito. Nele, embora estranhos, os acontecimentos improváveis encontram de alguma forma, possibilidades reais. Ambientado na pequena e bucólica cidade de Manarairema o romance é dividido em três partes, $A$ Chegada, quando um grupo de estrangeiros chega a pequena cidade de Manarairema; $O$ Dia dos Cachorros, quando se narra um grande derrame de cães pela cidade; e sua parte final com O Dia dos Bois, momento no qual o insólito flerta com o surreal e o inverossímil, tornando o ambiente sufocante a partir do sítio de bois à Manarairema. Um bela leitura sobre a chegada dos estranhos à cidade nos é dada por Prado:

Vista em perspectiva, a vida em Manarairema, depois deles [os estrangeiros], se acelera: pessoas perguntam pelos estranhos visitantes, há gente que não dorme, que os vigia de longe, que pergunta pelas ruas, que recebe informes suspeitos, mas a verdade é que, no limite, afora uns breves e atrevidos contatos, aqueles homens, a rigor não se constituem numa grave ameaça. No fundo, eles só se justificam na trama como signo de motivação literária que ganham importância na mediada em que desencadeiam uma reação coletiva que enriquece de temas e de cores, de episódios e de descrições paralelas os bastidores de uma realidade social entorpecida pela miséria e o esquecimento. (PRADO, 2015, p.15-6).

Na verdade, podemos perceber que a partir da chegada dos Homens da Tapera, acampados nos arrabaldes da cidade, inicia-se uma inversão das relações de poder e autoridade, algo que ficará mais nítido com as mudanças de Amâncio Mendes, comerciante que de desafiante ao poder dos estrangeiros, sucumbirá e se entregará ao novo status quo estabelecido na cidade:

Aí é que está o seu erro. Você fala como se não tivesse acontecido nada. Direitos? Que direitos! Quem não deve não teme! Tudo isso já morreu. Hoje em dia não é preciso dever para temer. Por que é que você acha que eu estou aqui pedindo, implorando, me rebaixando? Eu devo alguma coisa? E você já me viu com medo algum dia? Você precisa entender que não estamos mais naquele tempo... (VEIGA, 2015, p.74).

No mesmo sentido, a relação entre os habitantes da cidade e os outros recém chegados é construída em expectativas, sejam elas positivas ou negativas, como vemos no seguinte trecho:

Só as crianças estavam refugando as novidades trazidas pelos homens da tapera. A Gente grande era cheia de prudências, de conveniências, de esperanças de vantagens, ou então simples medo. Pessoas como Apolinário eram raras, e ficavam sozinhas, até 
as famílias vinham dar aqueles conselhos moles, baseados no olha-lá, pense-bem, émelhor-ceder. (VEIGA, 2015, p.117).

Assim, da chegada dos homens aos primeiros dias de contato e as novas relações entre eles construídas, quando encerra-se a primeira parte do romance "das intenções dos homens, de sua ocupação verdadeira a cidade continuava na mesma ignorância do primeiro dia" (VEIGA, 2015, p.57). Mas a partir da segunda parte do romance temos então a presença ainda mais forte do insólito, e com ela além do rompimento extravasado do cotidiano, temos a inversão da autoridade trazida com:

A vaga de pelos, de dentes, de patas, de rabos, de uivos chegou inteira e logo se espalhou por toda a parte farejando, raspando, acuando, regando pedras, barrancos, muros, raízes de árvores, unhando portas, choramingando, erguendo-se nas patas traseiras para ver se descobriam nas salas alguma coisa digna de atenção. (VEIGA, 2015, p.60).

Com isso, crescem os conflitos numa escalada de violência e arbitrariedade que culminará com a última de suas partes, a chegada dos bois à Manarairema:

Durante o resto do dia e ainda por toda a noite mais bois chegaram, pisando em tudo, derrubando casa de pobres, invadindo corredores de ricos, espremendo-se uns contra os outros, as cabeças levantadas para os chifres não se embaraçarem, sem espaço nem para erguer o rabo na hora de defecar, a matéria saindo forçada pelas pernas abaixo, breando tudo. (VEIGA, 2015, p.119).

A invasão dos bois à cidade representa o auge da repressão e da opressão existentes na trama. Sitiados em suas casas, os habitantes de Manarairema têm de lidar com a escassez de recursos, o medo, e sobreviver à fome. Nestes dias de sítio, apenas as crianças conseguem locomoverem-se por sobre os bois que tomam qualquer espaço possível da cidade. Nesse capítulo específico não deixamos de perceber que o insólito é extrapolado, praticamente rompido, estabelecendo o auge do clima de tensão e incapacidade do oprimido em relação ao opressor. Nesse momento específico, a própria verossimilhança é arrombada, como corpos e mortes para além da conta, e um insólito que beira ao surreal.

No final, da mesma forma como o insólito e o inesperado surgem em Manarairema, "de repente a descoberta" e assim como tinham se chegado, os homens e os bois somem sem qualquer explicação. "Primeiro foi um desassossego entre os bois, um estremecer de lombos e barbeias, um escovar de pés no chão; depois os berros cruzados, de aviso, de chamado" (VEIGA, 2015, p.131). No dia seguinte os habitantes "abrem as janelas" e descobrem-se livres dos bois e realizam um grande festejo. Esse desfecho do romance, aliás, levou a parte da crítica considerar Veiga otimista em relação ao regime, o que, segundo o próprio autor, teria levado-o a revisitar o tema em "Sombras de Reis Barbudos", (1972).

Para Luiz Roncari, "Sombras de Reis Barbudos" seria melhor acabado do que "A Hora dos Ruminantes", em grande parte pela "escolha do narrador subjetivo atenuando o contraste entre o regional e o insólito" de modo que percebemos "o peso maior dos elementos de contextos, histórico e literários, nas definições estilísticas e ficcionais do autor" (RONCARI, 2015, p.9). O romance é narrado pelo jovem Lucas, posteriormente aos acontecimentos relacionados à chegada da Companhia de Melhoramentos Taitara. $\mathrm{Na}$ abertura da narrativa ele já traça o ambiente desolado pós-fatos:

Está bem, mãe. Vou fazer sua vontade. Vou escrever a história do que aconteceu aqui desde a chegada de Tio Baltazar. Sei que esse pedido insistente é um truque para me prender em casa, a senhora acha perigoso eu ficar andando por aí mesmo hoje, quando os fiscais já não fiscalizam com tanto rigor. Talvez seja mesmo uma boa maneira de 
passar o tempo, já estou cansado de bater pernas pelos lugares de sempre e só ver tristeza de casas vazias, janelas e portas batendo ao vento, mato crescendo nos pátios antes tão bem tratados, lagartixas passeando atrevidas até em cima dos móveis, gambás fazendo ninhos nos fogões apagados, se vingando do tempo em que corriam perigo até no fundo dos quintais. (VEIGA, 2015, p.21).

Para Gegório Dantas, tanto em "Sombras de Reis Barbudos", "A Hora dos Ruminantes" e no conto "A usina atrás do Morro" as narrativas são construídas numa premissa comum: "a invasão da pequena cidade por estranhos que subvertem a ordem do lugar, impondo aos moradores um comportamento submisso e limitações absurdas" (DANTAS, 2002, p.97). O autor parte disso para discorrer sobre "o insólito como invasor do cotidiano", entretanto, como já discutimos aqui, a afiliação de gênero é algo que os autores não levam a sério, pelo contrário, geralmente eles buscam por violentar qualquer limitação deste tipo. Nesse sentido, talvez não seja possível observarmos "Sombras de Reis Barbudos" da mesma forma que "A Hora dos Ruminantes", pois a narrativa ao abordar a aplicação de ideologias totalitárias, no caso representadas pelas práticas da Companhia, parece ir para além do insólito, como transparece aqui:

De repente os muros, esse muros. Da noite para o dia eles brotaram assim retos, curvos, quebrados, descendo, subindo, dividindo as ruas ao meio conforme o traçado, separando amigos, tapando vistas, escurecendo, abafando. (...) Com tanto muro para encarar quando estávamos parados e rodear quando tínhamos de andar, a vida estava ficando cada dia mais difícil. (VEIGA, 2015, p.42-3).

Embora insólito, é mais fácil conceber o surgimento do nada de bois e cães, do que muros. Ainda que pudessemos pensar nesse "de repente" como algo metafórico ou simbólico a algo que foi sendo construído e que apenas depois de algum tempo é que do objeto se toma consciência, a sensação que surge na narrativa é como se eles brotassem do solo sem qualquer explicação razoável, como num passe de mágica. Além disso, o surgimento repentino dos muros é apenas um dos elementos que vão levar "Sombras de Reis Barbudos" um tanto além do simples insólito. Nesse sentido, o acontecimento mais emblemático e que por ele só exige outro artigo de reflexão, é o surgimento do homem voador. Os boatos já correm pela cidade de Taitara, mas a confirmação se dá quando Lucas finalmente o avista:

Mas uma tarde, quando eu regava a horta distraído, olhei para cima na maior inocência, nem estava pensando no tal homem voador, e dei com ele vindo do lado do rio (...) Vinha mais alto que o da torre [telhado], mas dava para distinguir os braços, as pernas, até as mãos de dedos abertos. Larguei o regador e corri para dentro. (VEIGA, 2015, p.2015).

A estranha experiência do narrador será por algum momento posta em dúvida, porém, no final do romance "ninguém estranha, todo mundo está voando apesar da proibição, só não voa quem não quer ou não pode ou tem medo. Mas naqueles primeiros dias foi um deus nos acuda, parecia o fim do mundo" (VEIGA, 2015, p.139-40). Nesse momento, a narrativa parece deixar as fronteiras do insólito para adentrar outras, não livres de debates e discussão.

Talvez aqui tenhamos saído dos insólitos terrenos, para adentrarmos realidades mágicas ou maravilhosas. De acordo com Monegal o "realismo mágico" pode ser interpretado como uma "adivinación poética o una negación poética de la realidad" (MONEGAL, 1976, p.176). Entretanto, chegando neste ponto de reflexão, vale ressaltar novamente que a estas discussões não desprezamos, tampouco desconhecemos todos os debates existentes nestas perspectivas de gênero, conforme mostra Rodríguez: 
Hablar de realismo mágico trae consigo unas claras dificultades frente a su definición, aunque este término ha sido utilizado comúnmente por escritores tanto latinoamericanos como europeos, éstos no han llegado a una definición clara y precisa sobre el mismo.( RODRÍGUEZ, 2000, p.12)

As dificuldades de que fala Camila Vilatte Rodríguez tratam da intensa discussão acerca das fronteiras e origens do realismo mágico e o realismo maravilhoso, temas de constante discussão nos estudos literários e cujas definições e debates nem sempre são pacíficos quanto aos termos. Isto posto, vale lembrar que o termo realismo mágico nasce na Europa, não na literatura, mas sim na pintura, quando Franz Roh usa o termo para falar da arte alemã pós expressionismo. Transposto para a literatura, de acordo com Irlemar Chiampi:

[o] realismo mágico veio a ser o achado crítico interpretativo que cobria de um golpe, a complexidade temática (que era realista de um outro modo) do novo romance e a necessidade de explicar a passagem da estética realista naturalista para a nova visão («mágica») da realidade (CHIAMPI, 1980, p.19).

Chiampi em seus estudos sobre o tema prossegue a discussão adentrando ainda ao realismo maravilhoso, que segundo ele:

Ao contrário da 'poética da incerteza' calculada para obter o estranhamento do leitor, o realismo maravilhoso desaloja qualquer efeito emotivo de calafrio, medo ou terror sobre o evento insólito ( ... ) Os objetos, seres ou eventos que no fantástico exigem a projeção lúdica de duas probabilidades externas e inatingíveis de explicação, são no realismo maravilhoso destituídos de mistério, não duvidosos quanto ao universo de sentido a que pertencem. Isto é, possuem probabilidade interna, tem causalidade no próprio âmbito da diégese e não apelam, portanto, à atividade de deciframento do leitor. (CHIAMPI,1980, p.59).

Prosseguindo as discussões, podemos considerar ainda que "para él (Carpentier) la literatura nace de lo «real», pero no de lo real natural sino de lo real maravilloso" (MONEGAL, 1976, p.188). Neste sentido:

O real maravilhoso brota de uma inesperada alteração da realidade..., de uma ampliação das escalas e categorias da realidade, percebidas com particular intensidade em virtude de uma exaltação do espírito que atinge uma situação limite. (ALCARAZ, 2005, p.23).

Retomando a linha de pensamento, trazemos até aqui algumas das discussões sobre o gênero responsável pelo boom da literatura fantástica na América Latina, e a citada força desta literatura no Brasil em seu decênio de 70, particularmente após o golpe militar de 1964. Aliás, vale fazer um destaque de que há certo distanciamento entre os debates desta literatura latino-americana, reconhecida mundialmente, e suas expressões na literatura brasileira, que geralmente não são trabalhadas ou reconhecidas como o conjunto do continente, o que de certo modo nos abriria novas possibilidades de discussão sobre este isolamento da produção nacional, mas que como viemos construindo neste debate, mostrou-se fortemente relevante em determinado período de nossa literatura. Todavia, tal insight pode ser revisitado noutras oportunidades. Retomemos aqui nossas leituras de José J. Veiga, que equilibrase entre o insólito e o realismo maravilhoso, e de Érico Veríssimo com "Incidente em Antares" de 1972, e cuja afiliação não causa grandes debates ou dúvidas quanto a sua afiliação. 
No caso do romance de Érico Veríssimo há certas provocações que inclusive "brincarão" com as questões referente ao gênero. A obra começa com a conhecida e provocativa nota do autor "neste romance as personagens e localidades imaginárias aparecem disfarçadas sob nomes fíctícios, ao passo que as pessoas e os lugares que na realidade existem ou existiram, são designados por seus nomes verdadeiros". De fato, as personagens ficcionais compartilharão o existir histórico com personalidades reais, e com isso produz um "retrato real" da sociedade brasileira em diferentes momentos de sua história. Todavia, não trata-se de um romance histórico, algo que fica bastante explícito pelo incidente:

O incidente que vai se narrar e que Antares foi teatro na sexta-feira, 13 de dezembro de 1963, tornou essa localidade conhecida e de certo modo famosa da noite para o dia - fama um tanto ambígua e efêmera, é verdade - não só no estado do Rio Grande do Sul como também no resto do Brasil e mesmo através de todo o mundo civilizado.( VERÍSSIMO, 1998, p.7).

Não há dúvidas que é pelo maravilhoso que se move o incidente a dar fama à Antares. $\mathrm{O}$ "teatro", falado pelo narrador de Veríssimo (com sua leitura bakhtiniana) refere-se a carnavalizada confusão criada no coreto de Antares, com a presença dos mortos insepultos, a nata da sociedade local, e nas bordas (e nas copas das árvores) a população em geral, o escracho. O fato estranho dá-se após o desencadear da greve geral (a qual aderem os coveiros) que estabelece a impossibilidade de sepultar seis diferentes personagens da cidade de Antares, e o que leva ao escatológico tribunal daquela sextafeira, quando as hipocrisias e desigualdades sociais são postas às claras pela boca putrefata dos digníssimos defuntos:

Nosso anarco-sindicalista acaba de me soprar um "fecho de ouro" para minha metáfora do baile de máscaras... Para vós o importante é que a festa continue, que não se toque na estrutura, não se alterem os estatutos do clube onde os privilegiados se divertem. A canalha que não pode tomar parte da festa e se amontoa lá fora no sereno envergando a triste fantasia e a trágica máscara da miséria, deve permanecer onde está, porque vós os convivas felizes achais que pobres sempre os haverá, como disse Jesus. E por isso pagais a vossa polícia para que ela vos defenda no dia em que a plebe decidir invadir o salão onde vos entregais às vossas danças, libações, amores e outros divertimentos. (VERÍSSIMO, 1998, p.344-5).

O discurso é feito pelo corrupto - e então defunto - advogado Cícero Branco, que aproveitandose da inimputabilidade que lhe confere a morte, em púlpito público realiza a delação de todas as corrupções e arbítrios do lugar. Destarte, embora dentro do real maravilhoso, é curioso observar a "operação borracha", artífice do poder local para levar ao esquecimento o estranho incidente. Além das relações e leituras disto para além da obra, internamente o trabalho de levar sua população ao esquecimento por diferentes meios, colocando-os no campo das incertezas, Érico nos remete ao fantástico tradicional que fala Todorov, estabelecendo na estrutura interna da obra a incerteza que constituir-se-á em importante mecanismo de poder, legando ao esquecimento todos os podres vindos à tona naquele dia 13 de dezembro de 1963, o que nos levaria a abrir outras frentes de discussão, como a relação entre poder e memória.

Mas retomemos o cenário e o ambiente conflagrado de Incidente em Antares, cuja sociedade polarizada em alegoria traça íntimos paralelos com as recentes experiências históricas vividas e vivenciadas pelo autor, testemunha dos golpes e contragolpes que constituíram a sociedade da época, em consequência os próprios traumas sociais. Nesse sentido, observemos que: 
La novela, de esta manera, se convierte en la contrapartida literaria de la naturaleza inhumana y de las relaciones inhumanas que describe: la novela está capturada entre las redes de la realidad inmediata y sólo puede reflejarla. (FUENTES, 1969, p.14).

Ademais, sem pretendermos apresentar um esquema de causa e consequência, convidamos a reflexões tomando em conta os interligamentos entre os fatores internos e externos da obra literária. Talvez de forma redundante, trouxemos até aqui relações do contexto social pré e pós 1964 que de certo modo podem ter conflagrado de vez "a ruptura com o pacto realista" apontada por Candido, seja por necessidade, por influências, etc. Neste sentido, observemos novamente Todorov, que mesmo limitando o campo do fantástico, deixa-nos pistas acerca de possíveis opções pelo gênero quando ele, Todorov, fala da função social e da função literária deste. Aliás, o reconhecimento num trabalho de vertente estruturalista, da parte social da obra literária é muito interessante. Sobre a função social do fantástico, diz ele:

Tomemos uma série de temas que provocam freqüentementea introdução de elementos sobrenaturais: o incesto, o amor homossexual, o amor a vários, a necrofilia, a sensualidade excessiva... Temos a impressão de ler uma lista de temas proibidos, estabelecida pela censura: cada um desses temas foi, de fato, freqüentemente proibido, e pode ser ainda em nossos dias. Além disso, ao lado da censura institucionalizada, existe outra, mais sutil e também mais generalizada: a que reina na psique dos autores. A condenação de certos atos pela sociedade provoca uma condenação que ocorre no próprio indivíduo, proibindo-o de abordar certos temas tabus. $\mathbf{O}$ fantástico é um meio de combate contra uma e outra censura: os desencadeamentos sexuais serão mais bem aceitos por qualquer espécie de censura se pudermos atribuí-los ao diabo. (TODOROV, 2006, p.160). [Grifos Nossos]

A partir desta premissa então se coloca "que a função social e a função literária do sobrenatural são uma única: trata-se da transgressão de uma lei” (TODOROV, 2006, p.160). Concentremo-nos então na expressão transgressão. Mas antes disso, reforçamos novamente que não se pretende aqui limitar as possibilidades que levaram a "proliferação" do fantástico no final da década de 60, e especialmente nos anos 70, pelo contrário, buscamos neste trabalho, ampliar essas possibilidades, levando em consideração, especialmente as relações entre o fantástico (e tudo que dele surgiu) e a sociedade.

Logo retomaremos a expressão "transgressão", mas antes, vejamos por exemplo, o relato dos bastidores da publicação de "Incidente em Antares" através de entrevista do editor da obra, José Otávio Bertaso:

Recebemos os originais e imediatamente os passamos à tipografia. $\mathrm{O}$ livro começou a ser composto antes mesmo que fosse editorado. Lá pela tantas, peguei os paquês e comecei a ler. Fiquei meio impressionado com algumas coisas que ali estavam. Cheguei à conclusão que se nós publicássemos o livro, ele poderia ser objeto de apreensão pela Censura Prévia que existia então. Bolamos um cartaz em negro com os dizeres: NUM PAÍS TOTALITÁRIO ESTE LIVRO SERIA PROIBIDO, o facsímile da capa, e, embaixo, a frase: 'à venda nas livrarias'. O cartaz estava sobre a mesa quando a pedagoga e psicóloga Juracy $C$. Marques, que à época estava publicando um livro conosco, viu a arte-final e nos alertou de que era muito agressivo e poderia nos causar problemas. (BERTASO apud BORDINI, 2006, p.277). 
Vejamos que transgressão aqui é algo que se aplica à obra em sua estrutura interna e também às suas etapas de produção. Além disso, buscamos demonstrar o quão limitados pela arbitrariedade do poder estavam os autores. O cenário era de censura prévia e o regime, embora nem sempre lembrado, tirou de circulação centenas de livros sob as mais diversas acusações, entre elas a generalista "atentar contra a moral e os bons costumes". Neste ambiente despótico e ditatorial (e não custa lembrar, como o restante do continente latino-americano), cabe-nos perguntar se seria possível aos autores manter o pacto realista. Até que ponto o que Todorov demonstra da capacidade de transgredir os tabus pelo fantástico, a opção por reunir a realidade aos elementos fantásticos e maravilhosos não seria uma boa forma, não só de driblar a censura existente no poder autoritário, mas também de resistência, transgressão? Uma transgressão que arrisca vários e perigosos limites, como o último parágrafo de "Incidente em Antares". Uma cena antológica, passada anos após as incertezas "plantadas" pela "Operaçao Borracha". Na cena, pai e filho andam pela rua:

O pequeno, entretanto, para demonstrar para os circunstantes que já sabia ler, olhou para a palavra de piche e começou a soletrá-la em voz muito alta: "Li-ber..." (...) Cala a boca, bobalhão! - Exclamou o pai quase em pânico. (VERÍSSIMO, 1998, p.485)

Nesse sentido, uma das possibilidades é que ao romper com o pacto realista, um rompimento que por sua vez rompe também com seus valores e intenções estéticas, os autores encontraram no fantástico ou em algumas de suas vertentes, como o insólito, o realismo mágico e o realismo maravilhoso presentes nas referidas leituras, uma forma não só de driblar o cenário de censura e perseguição imposto pelo Regime Militar, mas também uma ação de transgressão e resistência desnudando as hipocrisias sociais e os desmandos de uma sociedade marcada pelo despotismo, a violência e a arbitrariedade? Assim, quando os cachorros, os bois e os cadáveres de Veiga e Veríssimo invadem a realidade presente, usam do maravilhamento do sobrenatural, do estranho e do insólito para expor as pútridas vísceras de uma sociedade cuja realidade precisa ser extrapolada e ressignificada para que não só escape da censura mas também produzam novas reflexões acerca do mundo em que se vive. Ademais, o rompimento com o pacto realista acaba pela inclusão dos elementos do insólito e do maravilhoso produzindo uma forte crítica social que provoca uma espécie de acerto de contas com as hipocrisias da sociedade.

Além das questões de gênero abordadas, as próprias leituras e influências destes autores brasileiros entram nesta soma, sendo importante observar que há um cenário de fortes convergências decorrentes dos conflitos sociais que levam os autores brasileiros a romper com o realismo vigente para penetrarem por terrenos mais amplos e misteriosos, fundindo a realidade com a estupefação do maravilhoso e do insólito. Embora cientes de certa tradição no Brasil, como demonstrado neste trabalho e noutras pesquisas, são nas emblemáticas décadas de 60 e 70 que a produção fantástica adquire uma força inequívoca na ficção. Há, talvez, uma crítica ao próprio realismo que tem o pacto rompido por não conseguir abordar e discutir os novos/velhos dramas essenciais da sociedade, apresentando uma nova estética capaz de transgredir por meio das palavras. 


\section{REFERÊNCIAS}

ALCARAZ, R. C. Literatura fantástica borgiana e realismo mágico latino-americano. In: Fragmentos n.28/29, Florianópolis, 2005. 21-28pp.

BORDINI, M. G. Incidente em Antares: a circulação da literatura em tempos difíceis. In: Revista USP n.68: São Paulo, 2005/2006. 274-81pp.

CANDIDO, Antônio. A Educação pela noite e outros ensaios. Editora Ática: São Paulo, 1989.

CHIAMPI, lrlemar. O Realismo Maravilhoso. São Paulo, Perspectiva, 1980. 180p.

DANTAS, F. Gregório. O Insólito na Ficção de José J. Veiga. UNICAMP: Campinas, 2002. 196p.

FUENTES, C. La nueva novela hispanoamericana. Ed. Joaquín Mortiz. México, 1969. 98p.

GARCIA, Flávio. A banalização do insólito na narrativa de ficção como marca distintiva de um outro e novo gênero literário, o insólito banalizado: as tensões entre a questão do insólito e os conceitos que dela tentam dar conta na literatura da lusofonia - Brasil, Portugal e Galicia. Rio de Janeiro: 2007. Disponível em: <http://www.flaviogarcia.pro.br/textos/index.htm>. Acesso em: 17 abr. 2012.

GINZBURG, Jaime. Autoritarismo e Literatura: A História Como Trauma. 2000.

MONEGAL, Rodríguez, E. Borges por él mismo. Monte Ávila Editores. Caracas, 1980.

RODRÍGUEZ, C. V. Realismo Mágico latinoamericano, aproximaciones a su influencia en el periodismo de Héctor Rojas Herazo y Gabriel García Márquez. Pontificia Universidad Javeriana: Bogotá, 2000. 109p.

TODOROV, Tzevetan. As Estruturas Narrativas. Perspectiva: São Paulo, 2006.

VEIGA, J. José. A Hora dos Ruminantes.Companhia das Letras: São Paulo, 2015. 150p.

VEIGA, J. José. Sombras de Reis Barbudos. Companhia das Letras: São Paulo: 2015. 150p.

VERISSIMO, Erico. Incidente em Antares. Editora Globo: São Paulo, 1998. 488p.

Recebido em 03/01/2019

Aceito em 16/01/2019 